\title{
Вікові особливості реактивності автономної нервової системи під час переробки інформації різної модальності та інтенсивності пред'явлення сигналів
}

\section{Світлана Безкопильна}

Черкаський національний університет імені Б. Хмельницького, Науково-дослідний інститут фізіології імені М. Босого, Черкаси, Україна.

Адреса для листування: bezkopylnaya86@ukr.net

Отримано: 28.05.20; прийнято до друку: 20.07.20; опубліковано: 02.09.20

Резюме. У дослідженні взяли участь 116 учнів: діти 7-8, підлітки 10-11 і 13-14 та юнаки 16-17 років. Досліджували взаємодію когнітивної та автономної нервової систем (АНС) за умови переробки інформації в режимі диференціювання сенсомоторних реакцій вибору двох із трьох (РВ2-3) різної модальності та інтенсивності пред'явлення сигналів. Когнітивне завдання включало визначення модальності сигналу (форми фігури чи значення слова), швидкого й безпомилкового диференціювання лівою чи правою рукою рухової реакції або гальмування дії. За показниками нелінійного аналізу регуляції серцевого ритму (CP): частоти (HR), площі регулювання (S), періодичних (SD2) та аперіодичних (SD1) коливань кореляційної ритмографії (KР) вивчали механізми регуляції АНС у спокої та при переробці образної та вербальної інформації у режимі gol/nogo/gor з різною інтенсивністю іiі пред’явлення.

Зіставлення результатів дослідження кількісних і якісних характеристик виконання когнітивних та моторних завдань складних рухових реакцій диференціювання РВ2-3, а також показників нелінійного аналізу регуляції СР у дітей, підлітків та юнаків дозволило виявити різні варіанти інтегративних функцій мозку та реактивності АНС у вигляді посилення або послаблення їхньої взаємодії. Встановили, що успішність та швидкість виконання завдань щодо переробки й диференціювання інформації в режимі PB2-3, а також реактивність механізмів регуляції АНС знаходиться у залежності від модальності сигналу, інтенсивності їх пред’явлення та віку обстежуваних. У обстежуваних всіх вікових груп за умови пред’явлення вербальних сигналів в режимі РВ2-3 кількість помилок та час рухових реакцій більший, а реактивність АНС вища, ніж на образні сигнали. Зростання інтенсивності пред’явлення образної та вербальної інформації в режимі РВ2-3 підвищує кількість помилок, зменшує час рухової реакції та призводить до зростання реактивності механізмів регуляції АНС. У юнаків кількість помилок, час складних рухових реакцій РВ2-3 та реактивність АНС менша, ніж у дітей та підлітків.

Ключові слова: онтогенез, когнітивні функції, модальність сигналів, автономна нервова система, кореляційна ритмографія, реактивність.

\section{Age features of reactivity of the autonomic nervous system during the processing of information of different modality and intensity of signal presentation}

\section{Svitlana Bezkopylna}

Bohdan Khmelnytsky National University of Cherkasy, Cherkasy, Ukraine

Correspondence: bezkopylnaya86@ukr.net

Abstract. 116 pupils participated in the investigation: children of the age $7-8$, teenagers of the age 10-11 and 13-14 as well as youngsters of the the age 16-17 years. We investigated the interaction of the cognitive and the autoagenomous nervous systems on the condition of processing information in the goL/nogo/goR mode of 
different modality and intensity of providing signals. The cognitive task included defining the signal modality (the form of the figure, or the meaning of the word), quick and unmistakable reaction with the left ( $\mathrm{goL}$ ) or the right ( $g o R)$ hand or slowing the moving act (nogo). By the indicators of the non-linear analysis of the heart rhythm regulation: frequency (HR), the regulating area (S), periodical (SD2) and aperiodical (SD1) fluctuations of the correlative rhythmography $(\mathrm{CR})$ we studied the mechanisms of the autonomous nervous system regulation at rest and while processing the image and the verbal information in the gol/nogo/gor regime with different intensity of its providing.

Comparison of the qualitative and quantitative characteristics of doing cognitive and motor tasks of complex movement reactions of RV2-3 differentiation investigation results as well as indicators of the non-linear children's, adolescents' and youngsters' SR regulation analysis allowed to find out different variants of the integrative brain functions and the ANS reactivity as the enforcement or lessening of their interaction. We have established being successful and the speed of doing tasks in processing and differentiating information in the RV2-3 regime as well as the reactivity of the ANS regulation mechanisms are dependent on the signal modality, the intensiveness of their display, and the age of the persons examined. The examined people of all age groups on condition of displaying verbal signals in the RV2-3 regime quantity of mistakes and the time of movement reactions is greater and the ANS reactivity is higher than to the image signals. The intensiveness of the image and the verbal information displaying an increase in the RV2-3 regime raises the number of mistakes, reduces the time of the movement reaction, and leads to the increase of the ANS regulation mechanisms reactivity. The youngsters' quantity of mistakes, the time of complex movement reactions RV2-3, and the ANS reactivity are less than children's and adolescents' ones.

Keywords: ontogenesis, cognitive functions, modality of signals, autonomous nervous system, correlative rhythmography, reactivity.

\section{ВСТУП}

Актуальність дослідження взаємодії когнітивних функцій та автономної нервової системи за умови переробки складної інформації визначається тим, що за даними World Health Organization дисонанс нейрокогнітивних i вегетативних механізмів лежить в основі розвитку депресій та призводить до зниження працездатності, інвалідності та погіршення якості життя [1].

Вікові зміни переробки інформації та взаємодії моторних і когнітивних систем мозку при виконанні завдань різної інтенсивності i модальності у дітей, підлітків та юнаків вивчені недостатньо. Дослідження вікових особливостей функціонування когнітивних систем мозку при виконанні складних інформаційних завдань необхідне для розкриття механізмів розвитку вищих психічних функцій та розумової діяльності людини в онтогенезі [1].

3 літератури відомо, що мозок з одного боку сприймає, переробляє та утримує у пам'яті велику кількість інформації, а 3 іншого сам іiі генерує. Ось чому дослідження інтегративної функції мозку та його взаємодії 3 різними системами під час переробки інформації різної модальності й інтенсивності -актуальне питання фізіології та психофізіології. Характерною особливістю сьогодення є суттєве зростання впливу на людину різного роду інформаційних навантажень. Інтенсифікація навчального процесу відкриває широкі можливості в освоєнні учнівською та студентською молоддю інформаційного простору, диктує необхідність оптимізації навчального процесу 3 метою підвищення ефективності та збереження здоров'я, а також його оптимізації 3 використанням інформаційних технологій обумовлюють актуальність досліджень фізіологічного забезпечення цілеспрямованої інформаційної діяльності дітей, підлітків та юнаків.

Складність техніки й технологій, широке розповсюдження інформаційних та емоційних навантажень, а також кардинальні зміни у змісті шкільної освіти, впровадження в навчальний процес комп'ютерної техніки, мобільних телефонів, ігрових автоматів пред'являють підвищені вимоги до психофізіологічних функцій дітей та молоді. Виникає потреба в постійному вивченні, аналізі впливу когнітивних навантажень на зміни функціонального стану організму учнів 3 метою подальшого розуміння механізмів регуляції психофізіологічних станів під час інформаційної діяльності, виявлення надійних індикаторів іiі діагностики та запобігання розвитку несприятливих станів і погіршення стану здоров'я.

Відомо, що під час когнітивної діяльності формується специфічна функціональна система, яка включає фізіологічні функції мозку для сприйняття, переробки й утримання великої кількості інформації в пам'яті, планування дії, контролює гальмування та переключає увагу, формує витривалість, яка пов'язана 3 операційними та моторними функціями. Вивчення реакцій на сигнали різної 
Вікові особливості реактивності автономної нервової системи під час переробки інформачії різної модальності та інтенсивності пред'явлення сигналів

модальності в когнітивних підходах проводять за допомогою сенсомоторної хронометрії [2; 3 ; $4 ; 5 ; 6]$. Загальний механізм часу реакцій описується фактором швидкості, який має біологічну основу, та вимірюється й оцінюється швидкістю сенсомоторних реакцій [1;7].

На ВСР впливають різні фізіологічні механізми, більшість із них опосередкована симпатичною на парасимпатичними гілками автономної нервової системи. Передбачали, що показники ВСР можуть бути використані як індикатори активності АНC або симатопарасимпатичної рівноваги [8; 9].

Метою роботи було дослідити вікові особливості реактивності автономної нервової системи за умови переробки інформації різної модальності та інтенсивності пред'явлення сигналів.

\section{МАТЕРІАЛИ І МЕТОДИ ДОСЛІДЖЕНЬ}

В учнів 7-17 років досліджували функціональний зв'язок психофізіологічних характеристик сенсомоторних реакцій та реактивності АНС. Дослідження проводили відповідно до Хельсінкської декларації (прийнятої 1964 року в Хельсінкі, Фінляндія, і переглянутої в жовтні 2000 року в Единбурзі, Шотландія), схвалене Етичним комітетом університету. Дослідження сенсомоторних реакцій проводили на комп'ютерному пристрої «Діагност-1М» в режимі «нав'язаного ритму» [10]. Для когнітивного завдання використали нейрофізіологічний 3-стимульний тест диференціювання образних i вербальних подразників в режимі РВ2-3 [10; 1].

Перед початком роботи обстежувані отримували інструкцію, відповідно до якої потрібно було виконувати завдання в режимі РВ2-3, визначати модальність сигналу, форму фігури чи значення слів. При появі фігури «квадрат» швидко натискати правою рукою на праву кнопку, при появі на екрані фігури «коло» - пальцем лівої руки на ліву кнопку, а при пред'явленні «трикутника» (гальмівний подразник) - не натискати на жодну 3 кнопок. Дослідження починали 3 пред'явлення образних сигналів на швидкості 30 сигналів за хвилину і далі інтенсивність пред'явлення подразників дискретно збільшували та переходили до 60, 90 і 120 сигналів за хвилину.

При виконанні тестів звертали увагу на успішність виконання завдань, на недопущення помилок (пропуски сигналів, запізнювання або випередження реакції та ін.) і на максимальну швидкість моторної реакції. Для когнітивного навантаження використали 60-секундне диференціювання сигналів. Порядок i час пред'явлених сигналів варіював i був випадковим. Час експозиції сигналу складав $0.7 \mathrm{c}$, а тривалість паузи змінювалася випадковим способом по алгоритму, який закладений в програмному забезпеченні. Реєстрували час рухової реакції та загальну кількість помилок.

Після короткого відпочинку завдання повторювали, але для переробки інформації використовували вербальні подразники [1]. Обстежуваний також отримував інструкцію, згідно 3 якою потрібно було виконувати завдання в режимі РВ2-3, і при появі на екрані назви «тварин» швидко натискати пальцем правої руки на праву кнопку, на назви «рослин» - пальцем лівої руки на ліву кнопку, а на назви «предметів» (гальмівний подразник) - не натискати на жодну 3 кнопок.

Для визначення реактивності автономної нервової системи застосовували кореляційну ритмографію («КардіоЛаб», ХАІ МЕДІКА 2006). У стані спокою та під час виконання завдань щодо переробки образних і вербальних сигналів визначали показники нелінійного аналізу ВСР, періодичні та аперіодичні коливання і характеристики КР $[9 ; 11 ; 12]$. Реєстрували частоту серцевих скорочень (HR, уд/хв.), визначали максимальну амплітуду періодичних SD2 мс, що відображає активацію парасимпатичного відділу та аперіодичних коливань SD1 мс, що відображає активацію симпатичної ланки вегетативної регуляції ритму серця та площу скатерограми $\left(\mathrm{S}, \mathrm{Mc}^{2}\right)$, за формулою $\mathrm{S}=\left(\begin{array}{lllll}\mathrm{n} & \mathrm{x} & 1 & \mathrm{x} & \mathrm{w}\end{array}\right) / 4$, як сумарну активність обох відділів автономної регуляції $[8 ; 9 ; 11 ; 12 ; 13]$.

Статистичну обробку отриманих показників здійснювали в електронних таблицях Excel. Достовірність різниць між вибірками оцінювали за критерієм Стьюдента. Значимість вірогідних значень приймалась $\mathrm{p}<0.05$.

\section{РЕЗУЛЬТАТИ}

Результати виконання когнітивних тестів виявили залежність швидкості рухових реакцій та якості (кількість помилок) переробки образної і вербальної інформації в режимі РНВ2-3 від інтенсивності подачі сигналів та віку обстежуваних. У дітей, підлітків та юнаків у більшості випадків підвищення інтенсивності пред'явлення сигналів приводило до збільшення кількості помилок (рис. 1). 

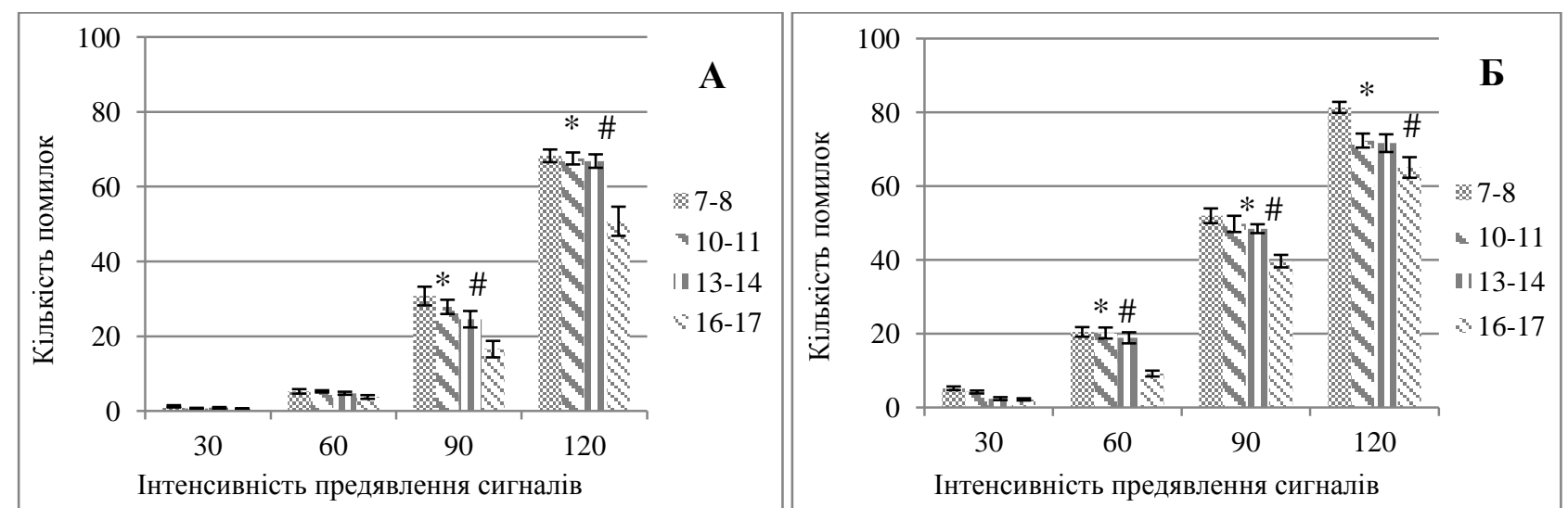

Рис 1. Кількість помилок під час переробки образних (А) та вербальних (Б) сигналів у когнітивному тесті РВ2-3

Примітка: *- статистично значимі відмінності між значеннями у дітей 7-8 років та обстежуваними старших вікових груп, \#-між значеннями у підлітків 10-11 та 13-14 і 16-17 років

3 рис. 1 видно, що кількість помилок за умови поступового зростання інтенсивності пред'явлення сигналів від 30 і далі до 60, 90 та 120 за хвилину збільшувалась у всіх вікових групах. Найменшу кількість помилок під час переробки інформації обстежувані всіх вікових груп робили за умови пред'явлення 30 сигналів за хвилину, а найбільшу при інтенсивності 120 подразників за хвилину. Крім того, встановили, що кількість помилок у режимі диференціювання РВ2-3 у завданнях на образні сигнали вірогідно менша, ніж на вербальні сигнали ( $<0.034-0.047)$, це спостерігається в обстежуваних кожної вікової групи. Статистично значимі відмінності виявили між дітьми 7-8 років, підлітками $10-11$ та 13-14 років 3 обстежуваними 16-17 років на пред'явлення образних сигналів при інтенсивності пред'явлення 90 і 120 подразників за хвилину, а на пред'явлення вербальних сигналів - на швидкості 60 і 90 сигналів за хвилину, при інтенсивності пред'явлення 120 подразників за хвилину статистично значимі відмінності виявили між дітьми 7-8 років та обстежуваними старших вікових груп, між обстежуваними підлітками $10-11$ та 13-14 років з обстежуваними $16-17$ років.

Аналіз результатів часу рухових реакцій у завданні $\mathrm{PB} 2-3 \quad 3$ поступовим зростанням інтенсивності пред'явлення сигналів засвідчив зменшення часу сенсомоторного реагування (рис. 2).

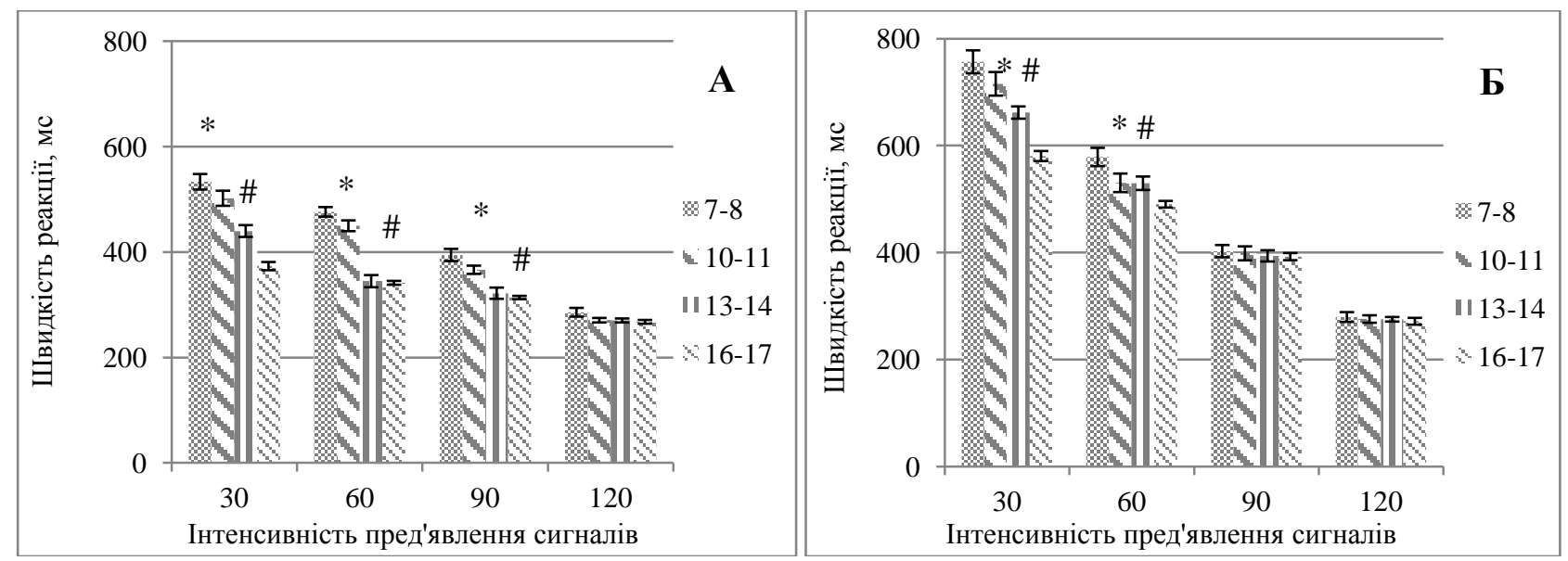

Рис 2. Швидкість реакиії під час переробки образних (а) та вербальних (б) сигналів y тесті PB2-3

Примітка: *- статистично значимі відмінності між значеннями у дітей 7-8 років та обстежуваними старших вікових груп, \#- між значеннями у підлітків 10-11 та 13-14і 16-17 років 
Вікові особливості реактивності автономної нервової системи під час переробки інформації різної модальності та інтенсивності пред'явлення сигналів

В обстежуваних дітей 7-8 років час рухових реакцій під час виконання когнітивних завдань на пред'явлення образних сигналів при інтенсивності пред'явлення 30 подразників за хвилину був $532.9 \pm 14.7$ мс, а $120-285.5 \pm 8.3$. В учнів 10-11 років - при інтенсивності пред'явлення 30 сигналів за хвилину був 501.7 \pm 14.3 мс, а на швидкості $120-270.4 \pm 4.3 \mathrm{мc,} \mathrm{у}$ підлітків 13-14 років - на швидкості 30 - 439.5 \pm 11.2 мс, а при інтенсивності пред'явлення 120 сигналів за хвилину $-269.9 \pm 3$ мс, а в юнаків 16-17 років час рухових реакцій при інтенсивності пред'явлення 30 подразників за хвилину був $373.0 \pm 7.8 \mathrm{мc}$, а на $120-267.4 \pm$ 3.6 мс. На пред'явлення вербальних сигналів час рухових реакцій у дітей 7-8 років при інтенсивності 30 сигналів за хвилину $-756.5 \pm$ 21.5 мс, а $120-279.2 \pm 9.2$ мс, в учнів $10-11$ років на швидкості 30 подразників за хвилину $715.3 \pm 22.1 \mathrm{мc}$, а при інтенсивності $120-275.5$ $\pm 7.0 \mathrm{мc}$, У підлітків 13-14 років - $661.6 \pm$ $11.5 \mathrm{мc}$, та $275.0 \pm 4.3 \mathrm{мс}$, відповідно, а в юнаків 16-17 років час рухових реакцій при інтенсивності пред'явлення 30 подразників за хвилину був $580.3 \pm 9.4 \mathrm{Mc}$, а на швидкості 120 $-271.3 \pm 6.4$ мс. Установили, що найбільший час рухових реакцій як на образні, так $\mathrm{i}$ вербальні подразники, був на швидкості пред'явлення 30 сигналів за хвилинув обстежуваних кожної вікової групи. 3 підвищенням швидкості пред'явлення подразників час рухової реакції для всіх обстежуваних поступово зменшувався i найвищих значень досягав на інтенсивності пред'явлення 120 сигналів за хвилину як для образних, так і вербальних подразників. Аналіз цих результатів нам дав змогу виявити наявність статистично значимих відмінностей між часом рухової реакції на образні i вербальні сигнали.

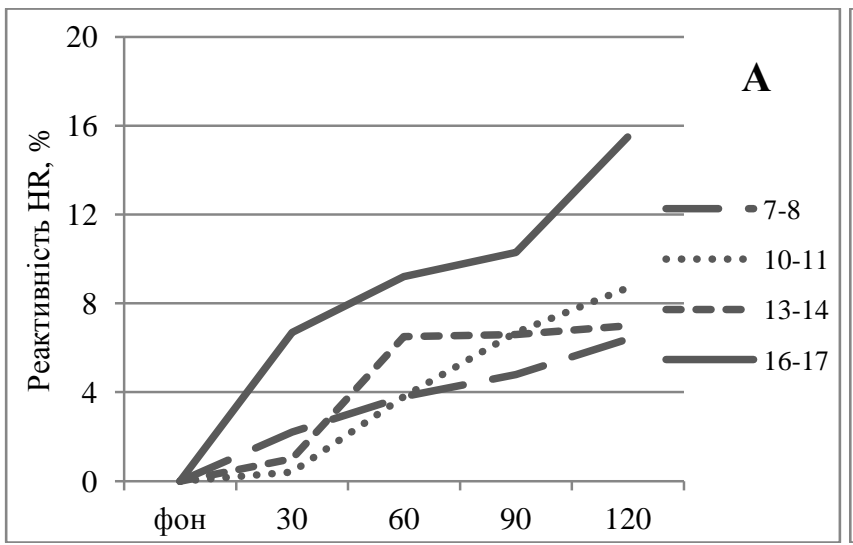

Результати показали, що успішність та якість виконання когнітивного завдання 3 переробки образної та вербальної інформації в режимі РВ2-3 знаходиться в залежності від інтенсивності пред'явлення та модальності сигналів і віку обстежуваних. У обстежуваних усіх вікових груп при зростанні інтенсивності пред'явлення сигналів від 30 і до 120 сигналів за хвилину поступово підвищується кількість помилок та зменшується час рухових реакцій. Встановлено, що час реакції в обстежуваних усіх вікових груп на образні сигнали в тестах 3 низькою 30 та середньою 60, 90 інтенсивністю пред'явлення сигналів менший, ніж на вербальні подразники, а кількість помилок нижча. На високій швидкості пред'явлення подразників 120 за хвилину час рухових реакцій як на образні, так i вербальні подразники був меншим, ніж у випадку переробки когнітивної інформації при інтенсивності 30, 60 та 90 сигналів за хвилину.

Результати дослідження активації АНC за характеристиками КР при переробці інформації різної модальності знаходились у залежності від інтенсивності пред'явлення сигналів їх модальності та віку обстежуваних. Застосування нелінійного аналізу ВСР та характеристик КР в ході виконання завдання 3 поступовим зростанням інтенсивності пред'явлення інформації від 30 і далі до 60, 90 та 120 сигналів за хвилину дозволило встановити поступове підвищення HR ( $<0.01-$ $0.001)$, яке супроводжувалося зниженням показників $\mathrm{S}$ та уповільненням SD2 і SD1 $(\mathrm{p}<0.047-0.012)$.

На основі цих даних вирахували реактивність АНС для обстежуваних усіх вікових груп.

3 малюнка видно, що 3 підвищенням швидкості пред'явлення сигналів, як образних,

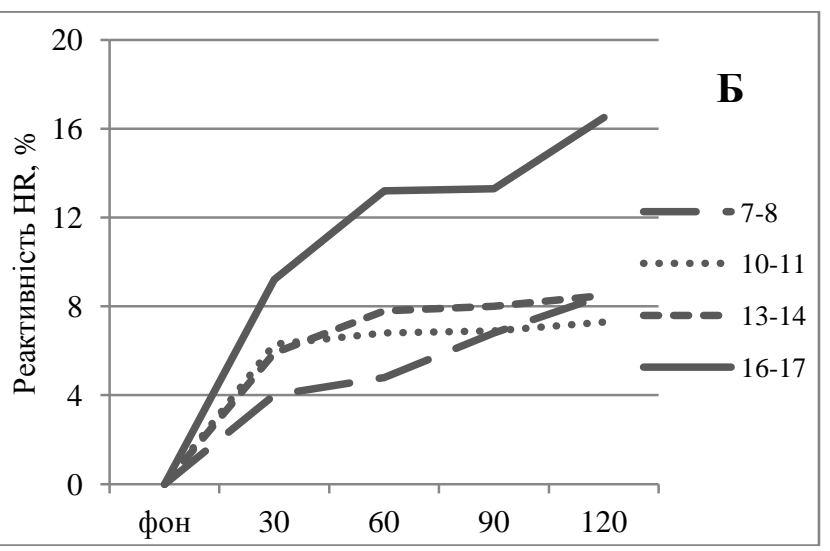

Рис. 3. Реактивність HR, \% на зростання інтенсивності пред' 'явлення образних (A) та вербальних (Б) сигналів у режимі РВ2-3 

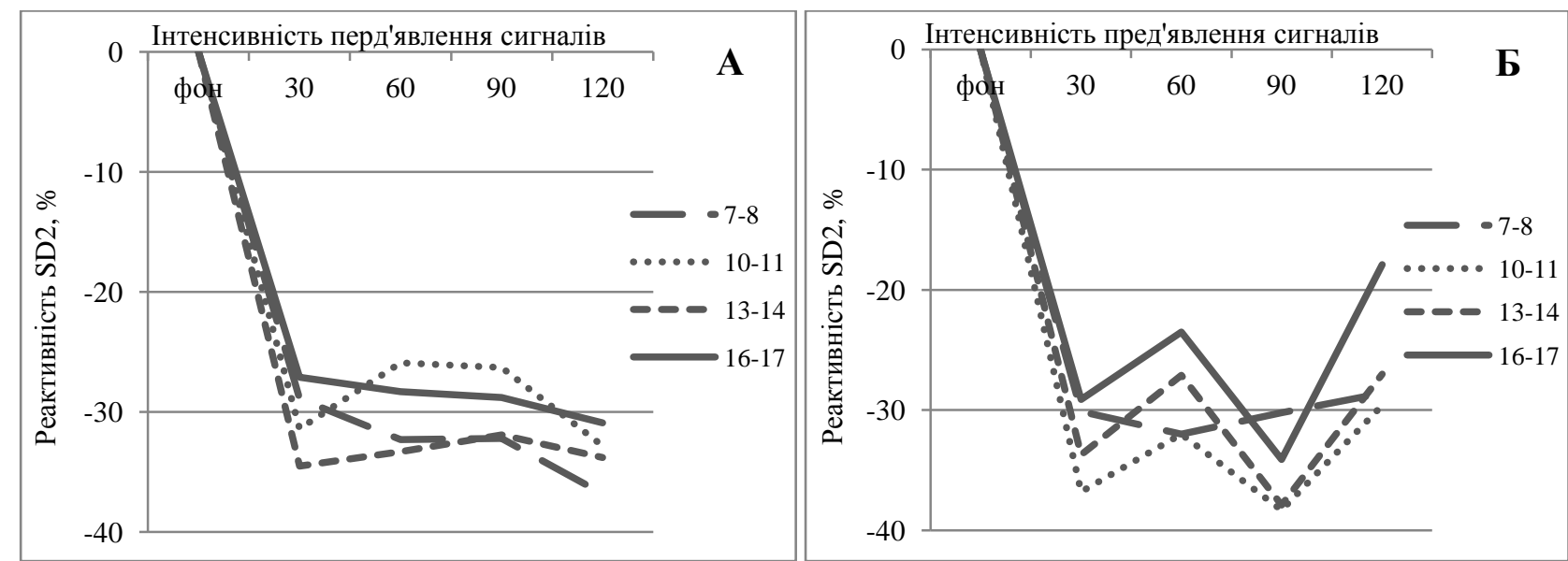

Рис. 4. Реактивність SD2, \% корелячійної ритмографії на зростання інтенсивності пред'явлення образних (А) і вербальних (Б) сигналів

так і вербальних, реактивність HR зростає в обстежуваних кожної вікової групи. Найвища реактивність виявлена на швидкості пред'явлення 120 сигналів за хвилину. Реактивність HR у дітей 7-8 років була найвищою і зросла на $15.5 \%$ на образні та на $16.5 \%$ на вербальні сигнали, тоді як в обстежуваних старших вікових груп вона зросла до 7-8\% на образні та 8.5\% на вербальні.

3 рисунка видно, що реактивність SD2 кореляційної ритмографії 3 поступовим підвищенням інтенсивності пред'явлення образних сигналів падає на $-27--34.5 \%$ і далі майже не змінюється, такі зміни відбуваються в обстежуваних усіх вікових груп. На пред'явлення вербальних подразників реактивність SD2 кореляційної ритмографії знижується на $-29--37 \%$. Наведені результати дозволяють стверджувати, що поступове зниження SD2 вказує на вплив зростаючого когнітивного навантаження на періодичні коливання СР і може свідчити про зниження активаційних процесів у парасимпатичній ланці AHC.

Аналіз аперіодичних коливань за показниками SD1 кореляційної ритмографії до початку виконання когнітивного завдання в обстежуваних не виявив суттєвих відмінностей середніх значень на вербальні та когнітивні сигнали ( $\mathrm{p}>0.067)$. Під час виконання завдань 3 поступовим зростанням інтенсивності пред'явлення когнітивної вербальної та образної інформації в режимі РВ2-3 від 30 і далі до 60, 90 та 120 сигналів за хвилину спостерігали поступове зниження реактивності SD1 $(\mathrm{p}<0.01-0.001)$ в обстежуваних усіх вікових груп. Найбільше зниження реактивності виявлено в дітей 7-8 років при пред'явленні образних сигналів на швидкості 90 і 120 подразників за хвилину $(-30 \%)$. В обстежуваних старших вікових груп цей показник знизився на $-16-20 \%$. На пред'явлення вербальних сигналів зміни реактивності відбувалися хвилеподібно.
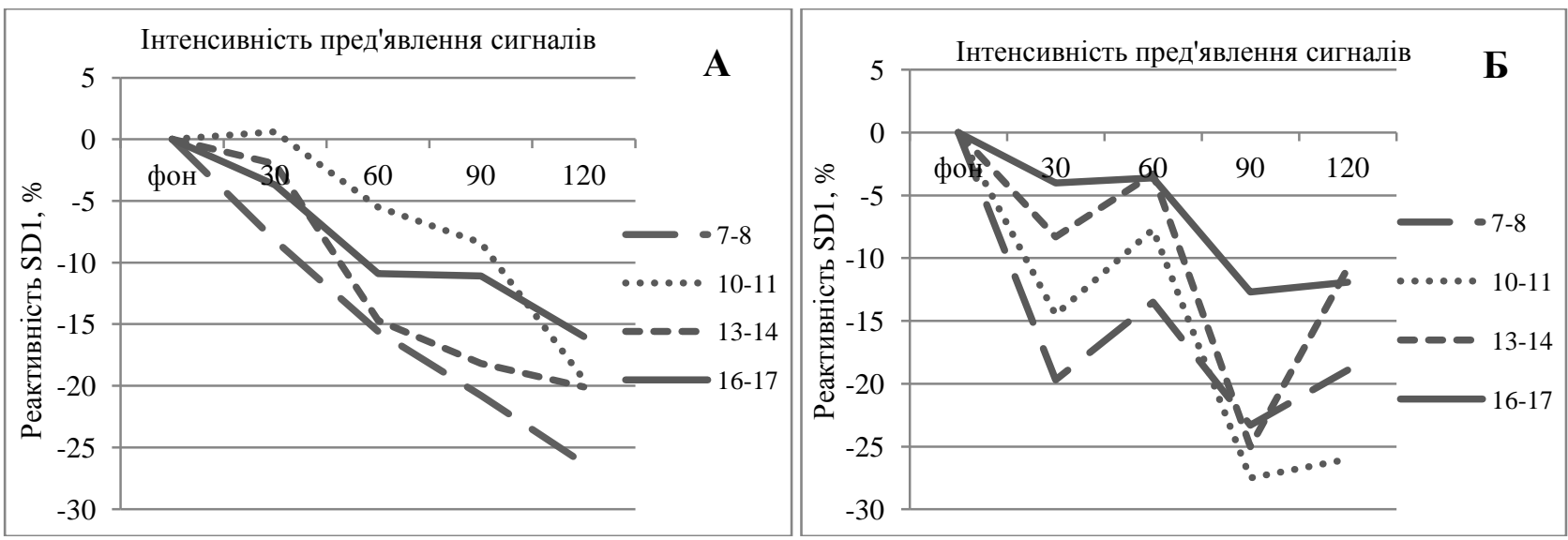

Рис. 5. Реактивність SD1, \% кореляџійної ритмографії на зростання інтенсивності пред’явлення образних (А) і вербальних (Б) сигналів у режимі РВ2-3 
Вікові особливості реактивності автономної нервової системи під час переробки інформації різної модальності та інтенсивності пред 'явлення сигналів

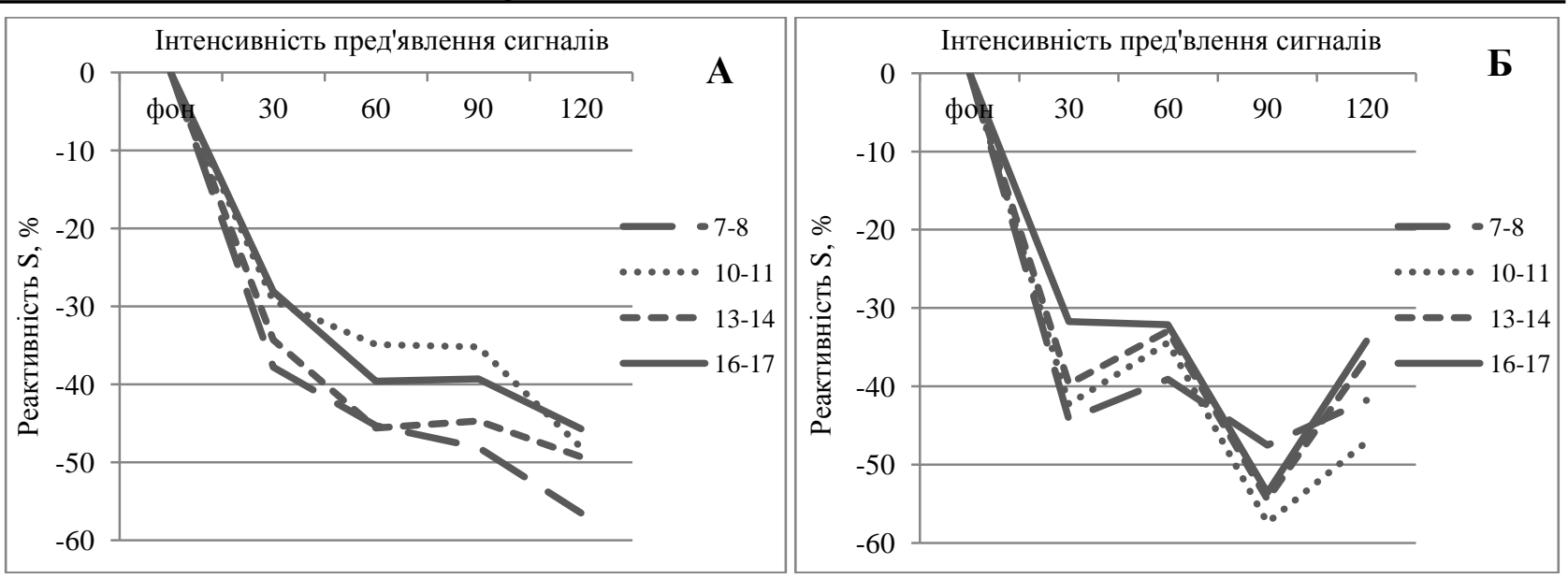

Рис. 6. Реактивність площі кореляційної ритмографії $S \%$ на зростання інтенсивності пред 'явлення образних (А) і вербальних (Б) сигналів у режимі диференціювання РВ2-3

В усіх обстежуваних найбільше зниження реактивності відбувалось на швидкості пред'явлення 90 сигналів за хвилину $(-12--27.5 \%)$.

3 цих результатів можна зробити узагальнення, що 3 підвищенням інтенсивності зростаючого когнітивного навантаження на АНC поступово зменшується амплітуда аперіодичних коливань SD1, що свідчить про зниження активаційних процесів у симпатичному відділі AHC.

Зростання інтенсивності переробки інформації в режимі РВ2-3 супроводжувалося зниженням показників площі регулювання $\mathrm{S}$ мс $^{2}$. За умови виконання завдань 3 поступовим зростанням швидкості пред'явлення подразників $30,60,90$ та 120 сигналів за хвилину реактивність площі регулювання поступово зменшувалась на $30-40 \%$ i досягала найнижчих значень $-45--56 \%$ для образних сигналів на швидкості 120 за хвилину, а для вербальних на швидкості 90 сигналів за хвилину $-47--57 \%$. Зниження реактивності показника $\mathrm{S}$ в обстежуваних усіх вікових груп під час виконання когнітивних завдань 3 переробки інформації 3 поступовим підвищенням інтенсивності пред'явлення сигналів від 30 до 120 за хвилину може свідчити про зростання напруження в регуляторних системах СР за рахунок зниження впливу як періодичних, так i аперіодичних коливань кардіоінтервалів. Це можна розглядати як вплив зростаючого когнітивного навантаження на зниження активації АНC парасимпатичного й симпатичного їі відділів.

\section{ОБГОВОРЕННЯ}

Проведене дослідження показало, що успішність та швидкість переробки інформації знаходиться в залежності від модальності сигналів, інтенсивності їх пред'явлення та віку обстежуваних. Можна припустити, що обстежувані мають неусвідомлену навичку підвищувати швидкість рухових реакцій за умови зростання інтенсивності пред'явлення для диференціювання сигналів у режимі РВ2-3 до 30 та 60 за хвилину. Водночас ми спостерігали значне зростання помилкових реакцій, що вказує на зниження ефективності, успішності та якості переробки інформації, а також переважання гальмівних процесів [14]. Відомо, що гальмівний контроль лежить в основі регуляції стресових станів, і якість гальмівного контролю обумовлює ефективність рішень, які приймаються [15], а інтенсивність 90 для вербальних та 120 за хвилину для образних сигналів можна вважати сильним стресором.

Переробка когнітивної 3-стимульної інформації знаходиться в залежності від вибору модальності пред'явлення сигналів. Так, у тестах із диференціювання РВ2-3 слів збільшувався час реакції (швидкість знижувалась) i знижувалась успішність виконання (зростала кількість помилок) порівняно 3 когнітивними завданнями із застосуванням фігур. Імовірно, що в когнітивних завданнях із застосуванням вербальних сигналів, крім сенсорної і моторної інтеграції, мають місце більш складні когнітивні процеси вищих відділів ЦНС, що характеризуються розподілом і переключенням уваги, мобілізацією пам'ятних слідів, 
диференційованим аналізом i формуванням програми дій [16; 17].

Найбільш цікаві результати отримали під час дослідження швидкості виконання когнітивного завдання на вербальні подразники. Визначили, що швидкість виконання комбінованого когнітивного завдання в 3-стимульній парадигмі РВ2-3 для образних сигналів проходить швидше, ніж для вербальних сигналів $(\mathrm{p}<0.023-0.043)$. Можна висловити припущення стосовно механізмів таких відмінностей. Насамперед аналіз образних сигналів забезпечується роботою першої сигнальної системи, до складу якої входить велика кількість коркових i підкоркових структур, що характеризуються високою надійністю [18; 19]. На відміну від них, більш філогенетично молоді вербальні функції забезпечуються роботою другої сигнальної системи, яка більш кортикалізована в лобних ділянках, менш стабільна і має обмежений нейрофізіологічний ресурс [20].

Нейрофізіологічним механізмом, який пояснює зниження швидкості та успішності переробки інформації для когнітивного тесту із застосуванням вербальних сигналів у парадигмі PB2-3 може бути і інтерференція. Можливо, що під час виконання когнітивного завдання із застосуванням слів мала місце різниця в часі збудження різних ділянок мозку. Саме таке просторово - часове рознесення мозкової активності при виконанні когнітивних завдань описано раніше [21].

Зростання інтенсивності переробки інформації від 30 і до 60, 90, 120 сигналів за хвилину, так і складності виконання когнітивного завдання (фігури чи слова) в режимі РВ2-3 призводило до посилення активності механізмів регуляції СР.

Вікова динаміка функціональної реорганізації сенсомоторних реакцій та реактивність АНС знаходяться в залежності від модальності пред'явлення інформації. Успішність переробки інформації в режимі когнітивних завдань під час диференціювання сигналів в режимі PB2-3 на образні сигнали вища, ніж на вербальні сигнали в усіх вікових групах. При переробці інформації в режимі PB2-3 кількість помилок на образні сигнали завжди менша, ніж на вербальні подразники. Для всіх вікових груп результати успішності виконання когнітивних завдань вищі на образні і нижчі на вербальні сигнали.

Встановлено залежність швидкості переробки інформації і показників кореляційної ритмографії ЧСC, SD2, SD1 та S. Чим вищою була інтенсивність пред'явлення сигналів, тим вищою була реактивність АНС та участь механізмів регуляції серцевого ритму $(\mathrm{p}<0.034-0.047)$.

\section{ВИСНОВКИ}

Доведено, що успішність та швидкість виконання завдань щодо переробки й диференціювання інформації знаходиться в залежності від модальності сигналу, інтенсивності їх пред'явлення та віку обстежуваних. Встановлено, що під час виконання завдання з низькою 30 та середньою інтенсивністю 60 і 90 сигналів за хвилину швидкість сенсомоторної реакції на образні вища, а кількість помилок нижча, ніж на вербальні сигнали $(\mathrm{p}<0.034-0.047)$. У випадку підвищення інтенсивності пред'явлення для диференціювання сигналів до 120 за хвилину швидкість сенсомоторної реакції на образні і вербальні сигнали була однаково високою $(\mathrm{p}>0.065)$. У юнаків 16-17 років час сенсомоторної реакції на різній інтенсивності їх пред'явлення образних i вербальних сигналів вищий, а кількість помилок нижча, ніж у дітей 7-8, підлітків $10-11$ та $13-14$ років $(\mathrm{p}<0.034-$ 0.047).

Виявили, що реактивність автономної нервової системи та їх механізмів регуляції СР знаходиться у залежності від модальності сигналу, інтенсивності їх пред'явлення та віку обстежуваних. Зростання інтенсивності пред'явлення образної та вербальної інформації в режимі РВ2-3 підвищує активність АНС у регуляції СР $(\mathrm{p}<0.034-0.047)$ Чим інтенсивніше пред'являли для диференціювання сигнали, тим вищою була реактивність АНС та участь механізмів регуляції СР ( $<<0.034-0.047)$. В обстежуваних усіх вікових груп за умови пред'явлення вербальних сигналів реактивність АНС вища, ніж на образні сигнали $(\mathrm{p}<0.034-0.047)$. За показниками КР за умови різної інтенсивності пред’явлення сигналів реактивність АНC у юнаків нижча, ніж у дітей та підлітків $(\mathrm{p}<0.034-0.047)$.

\section{ЛITЕРАТУРА}

1. Lyzohub, V. S.; Chernenko, N. P.; Kozhemiako, T. V.; Palabiyik, A. A.; Bezkopylna, S. V. Age peculiarities of interaction of motor and cognitive brain systems while processing information of different modality and complexity. Regulatory Mechanisms in Biosystems. 2019, 10(3), 288-294. DOI:10.15421/021944 
Вікові особливості реактивності автономної нервової системи під час переробки інформації різної модальності та інтенсивності пред 'явлення сигналів

2. Makarenko, M. V.; Lizohub, V. S.; Galka, M. S.; Yuhimenko, L. I.; Khomenko, S. M. Method of psychophysiological evaluation of the functional state of the auditory analyzer. Patent. 96496 State Service for Intellectual Property of Ukraine, MPC A 61B5/16. № 2010 02225; stated. 01.03.2010; published Nov 10, 2011, Bul. No. 21

3. Goodwin, J. C.; Goodwin K. A. Research in Psychology. Methods and Design. Danvers, MA, USA: John Wiley \& Sons. 2016, 560.

4. Kirsch W.; Hoffmann J. Stimulus-dependent modulation of perceptual and motor learning in a serial reaction time task. Advances in Cognitive Psychology. 2012, V, 8(2), 155. DOI: 10.2478/v10053-008-0112-2

5. Levy-Tzedek, S.; Hanassy, S.; Abboud, S. et al. Fast, accurate reaching movements with a visual-toauditory sensory substitution device. Restorative neurology and neuroscience. 2012, V, 30(4), 313. DOI: 10.3233/RNN-2012-110219

6. Broggin, E.; Savazzi, S.; Marzi, C. A. Similar effects of visual perception and imagery on simple reaction time Q.J. Exp. Psychol. (Hove). 2012, V, 65. Issue 1. 151. DOI: 10.1080/17470218.2011.594896

7. Jensen, A. R. Clocking the Mind: Mental Chronometry and Individual Differences. Elsevier: Oxford (UK), Amsterdam (Netherlands), 2006, 272.

8. Баевский, Р. М. Проблемы оценки и прогнозирования функционального состояния организма и ее развитие в космической медицине. Успехи физиологических наук. 2006, Т. 37, № 3, 4349.

9. Вариабельность сердечного ритма: стандарты измерения, физиологическая интерпретация и клиническое использование. Рабочая группа Европейского общества кардиологов и Североамериканского общества стимуляции и электрофизиологии. Ин-т кардиол. техники: СПб. 2000, 82.

10. Макаренко, М.В.Методика проведення та оцінки індивідуальних нейродинамічних властивостей вищої нервової діяльності людини. Фізіологічний журнал. 1999, Т. 45, № 4, 123-131.

11. Данилова, Н. Н.; Астафьев, С. В. Внимание человека как специфическая связь ритмов ЭЭГ с волновыми модуляторами сердечного ритма. Журн. Высти. Нервн. Деят. 2000, Т.50, № 5, 791-800.
12. Guzik, P.; Piskorski, J.; Barthel, P.; Bauer, A.; Müller, A.; Junk, N.; Ulm, K.; Malik, M.; Schmidt, G. Heart rate deceleration runs for postinfarction risk prediction. J Electrocardiol. 2012, 45(1), 70-76. DOI: 10.1016/j.jelectrocard.2011.08.006

13. Гаврилова, Е. А. Вариабельность ритма сердца и спорт. Физиология человека. 2016, 41(5), 121-129. DOI: 10.7868/S0131164616050088

14. Леутин, В. П.; Николаева, Е. И. Психофизиологические механизмы адаптации $и$ функциональная асимметрия мозга. Наука: Новосибирск, 1988, 193.

15. Liston, C.; McEwen, B. S.; Casey, B. J. Psychosocial stress reversibly disrupts prefrontal processing and attentional control. Proceedings of the National Academy of Sciences. 2009, V, 106(3), 912914.

16. Donker, S.; Roerdink, M.; Greven, A.; \& Beek, P. Regularity of center-of- pressure trajectories depends on the amount of attention invested in postural control. Experimental Brain Research. 2007, 181(1), 1-11. DOI: 10.1007/s00221-007-0905-4

17. Doumas, M.; Rapp, M. A.; \& Krampe, R. T. Working memory and postural control: adult age differences in potential for improvement, task priority, and dual tasking. The journals of gerontology. Series $B$, Psychological sciences and social sciences. 2009, 64, 193-201. DOI:10.1093/geronb/gbp009

18. Bernstein, N. A. Contemporary Studies on the Physiology of the Neural Process. Smysl: Moscow, 2003, 330 .

19. Horak, F. B. Postural orientation and equilibrium: what do we need to know about neural control of balance to prevent falls? Age and Ageing. 2006, 35(2), 7-11. DOI: 10.1093/ageing/af1077

20. Лурия, А. Р. Основы нейропсихологии. Академия: Москва. 2004, 384 с.

21. Zhavoronkova, L. A.; Kuptsova, S. B.; Zharikova, A. V.; Kushnir, E. M.; \& Mikhalkova, A. Harakteristika izmeneniy reaktivnosti EEG pri vyipolnenii dvoynyih zadaniy $\mathrm{u}$ zdorovyih sub'ektov (dobrovolnyiy posturalnyiy kontrol i raschet). Human Physiology. 2011, 37(6), 688-699. DOI: $10.1134 / \mathrm{S} 0362119711060168$ 